brazilianpoliticalsciencereview

\author{
ARTICLE
}

\title{
Freedom through form: Bolívar Lamounier and the Liberal Interpretation of Brazilian Political Thought*
}

\author{
Christian Edward Cyril Lynch \\ Universidade Estadual do Rio de Janeiro, Rio de Janeiro, Rio de Janeiro, Brazil \\ Paulo Henrique Paschoeto Cassimiro \\ Universidade Estadual do Rio de Janeiro, Rio de Janeiro, Rio de Janeiro, Brazil
}

\begin{abstract}
This article examines the contribution of Bolívar Lamounier to Brazilian political thought. Our main argument is that, by replacing nationality with freedom as the defining criterion of the real, Bolívar Lamounier offers a liberal interpretation of Brazilian political thought, in direct contrast to the nationalist tradition formulated by Oliveira Vianna. In this view, it is the liberals who are the realists, while nationalists and Marxists are idealists. As we shall see, this interpretation is normatively committed to one side, that of liberalism, guided by the aspiration to establish institutions that will foster the autonomous flowering of the market and civil society in opposition to a state prone to authoritarianism.
\end{abstract}

Keywords: Brazilian political thought; Bolívar Lamounier; nationalism; liberalism; democracy.

(*) http://dx.doi.org/10.1590/1981-3821201800020002

This publication is registered under a CC-BY Licence.

The authors would like to thank the attentive reading of Bernardo Ricupero, Bernardo Ferreira and Ivo Coser, as well as those of anonymous reviewers, whose comments and contributions have enriched the final version of the article. 
ince ancient times, thinkers have taken social life as their object of analysis and reflection for understanding the nature of power or, normatively, the best form of government. Depending on the disciplinary field, methodology and national tradition, this set of reflections has been defined by different names: political philosophy, political theory, political thought, history of political thought, history of political ideas or history of political doctrines (CASTIGLIONE and HAMPSCHER-MONK, 2001). In order to try and map this two-and-a-half thousand-year history of authors and works, scholars have devoted themselves to formulating classifications capable of providing some basic intelligibility. The most popular of these has been the division between 'idealists' and 'realists'. The former, such as Plato, Locke, and Kant, would be identified with ethical or normative views, while the latter, such as Machiavelli, Hobbes, and Schmitt, would have a commitment to more descriptive analyzes. As early as the nineteenth century, in works such as the 'History of Political Science', charting its relationship to morality, Paul Janet classified the authors according to that dichotomy, seeking a middle ground between them (JANET, 1887 [1872]). In the twentieth century, American political science consecrated the formula with the publication of The Machiavellians, a true bestseller in which James Burnham (1943) offered a fervent declaration of realist faith. Around the same time, the dichotomy also emerged as central to the study area of international relations, thanks to the seminal work of Edward $\mathrm{H}$. Carr, Twenty Years of Crisis 1919-1939 (2001). Thereafter, it would be restated by numerous authors, such as Hans Morgenthau (2003) and Raymond Aron (2002).

The fundamental divergence between realists and idealists revolves around whether it is possible to modify the ethical conduct of individuals from a higher level. Other points of divergence relate to the capacity of human beings to discover 'laws' of social reality; to the ethical status of this reality in relation to an ideal model of society; and, finally, to the capacity of political action to reduce the distance between the real and the ideal. It is important to add that those who took the most care when adopting the dichotomy in political science and international relations, compelled by the epistemological demands themselves, professed realistic faith and offered greater or lesser praise of other authors who seemed committed to that perspective.

Similar efforts have accompanied interpretations of Brazilian political thought in recent decades, understood as a "set of ideological writings representative of Brazilian political culture, marked by a peripheral style of reflection" (LYNCH, 2016, pp. 
75-76). Some of our most eminent political scientists have taken up the challenge of mapping lineages, ideologies and intellectual traditions using the same general dichotomy between idealism and realism. Although the first effort appears to go back to Joaquim Nabuco's 'Estadista do Império' (A Statesman of the Empire), in which he deploys Paul Janet's categories to make the case for a practical form of idealism (NABUCO, 1997), the first classification to attract the attention of national politics was that between 'utopian idealism' and 'organic idealism', established by Oliveira Vianna (1922) in 'O Idealismo na Evolução Política do Império e da República' (Idealism in the Political Evolution of the Empire and the Republic). Adopting an understanding of political realism that took into account the particularities of Brazil's historical and social formation, Vianna (1922) condemned liberal reformers, like Ruy Barbosa, who seemed to ignore "the real and organic conditions of societies that they intend to govern and direct", as utopian idealists. Organic idealists, in his view, were those who, because they fed on "reality, which only relies on experience, which is guided only by the observation of people and the environment," would be able to effectively "anticipate visions of future reality" (VIANNA, 1922, pp. 14-17). This classification, which suggested a rejection of cosmopolitan formulas as an expression of intellectual alienation, was reiterated in the 1950s by Guerreiro Ramos, who was interested in creating a sociology mainly concerned with Brazilian problems. Having, throughout his career, referred to the 'idealist vs realist' dichotomy by different names, he finally settled on 'hypercorrect' and 'criticalpragmatic' terms (RAMOS, 1983, p. 533). With the institutionalization of Brazilian Political Science in the second half of the 1960s, members of the pioneering generation, such as Wanderley Guilherme dos Santos and Bolívar Lamounier, turned their attention to Brazilian political thought, seeing it as a valuable repository of material that would be indispensable for understanding our political culture and the formulation of hypotheses susceptible to empirical verification (LYNCH, 2017a). In this way, both developed their research at practically the same time, against a background of international debates around authoritarianism that dominated the Spanish and Portuguese literature.

Santos's interpretation, which started with a desire to understand the origins of ISEB's nationalist thinking but ended up assuming a much broader character, was elaborated in several publications between 1965 and 1978, the most famous being the last two: Paradigma e História (Paradigm and History), and Práxis Liberal no Brasil (Liberal Praxis in Brazil) (SANTOS, 1978). In these works, Santos (1978) argued that 
Brazilian authors were primarily (though not exclusively) divided between two main currents: instrumental authoritarianism and doctrinal liberalism. The doctrinaire liberals were idealists and believed in the efficacy of universal formulas regardless of the particularities of each country, thus falling into 'institutional reification'. On the other hand, instrumental authoritarians were realists, who, though equally desirous of achieving the liberal and capitalist ideal, perceived socio-economic backwardness as an insurmountable obstacle to the free operation of institutions and, therefore, preferred to allocate to the state the role of "setting the goals for which society should fight, because society itself would not be able to fix them, in the pursuit of maximizing national progress" (SANTOS, 1978, p. 106). Like the classifications of Oliveira Vianna and Guerreiro Ramos, to the extent that the criteria used to define 'reality' depends on knowledge of the national reality, it is legitimate to define this interpretation as 'nationalist', without adopting any value judgment.

Acknowledging that there are already works dedicated to the interpretations of Ramos and Santos (LYNCH, 2013, 2015), the present article is dedicated to examining that of political scientist Bolívar Lamounier. The relevance of Lamounier's work lies not only in its novelty, but also in the considerable influence it has exerted on the interpretations and definitions of the so-called 'authoritarian Brazilian thought'. The hypothesis we will put forward is that, insofar as its classification replaces nationality with freedom as the defining criterion of the real, Bolívar Lamounier formulates a liberal interpretation of Brazilian political thought, in stark contrast to the nationalist tradition inaugurated by Oliveira Vianna. In his works, it is the liberals who figure as the realists, while nationalists, and also Marxists, are the idealists. As we shall see, his interpretation is also normatively committed to one side, that of liberalism, guided by the aspiration to establish institutions more likely to foster the autonomous flowering of the market and civil society in opposition to a state prone to authoritarianism.

From conservative thought to authoritarian ideology: in search of theories and analytical models (1968-1974)

Bolívar Lamounier's reflections on political thought began even before he undertook post-graduate studies at the University of California. In the wake of the military coup of 1964, he was interested in understanding Brazilian authoritarian culture. As a starting point, he drew on Paulo Mercadante's reflections in 'A Consciência 
Conservadora no Brasil' (Conservative Consciousness in Brazil) (1965), in which the author described Brazil's political evolution as a constant mediation between elites to balance the demands of economic liberalism and the interests of agrarian oligarchies. In his first article on the subject, called Ideologia conservadora e mudanças estruturais (Conservative ideology and structural changes) (LAMOUNIER, 1968), Lamounier argued that this conciliatory mentality among elites probably emerged from the experiences of the civil wars of the 1830s, after which they always sought to avoid conflict through cooptation and compromise. The state would be organized to manage party-political contestation and fill bureaucratic functions in a personalist and patrimonial way. This would explain the tendency of Brazilian culture towards demobilization and the negation of conflict. It so happens that, faced with new demands for recognition throughout the 1950s, the tendency, or possibility, of conciliation was exhausted. Formed from a narrow socioeconomic stratum linked to agricultural production and large rural property, the elite had not been able to produce party and bureaucratic systems capable of accommodating the emergence of new groups. The result was the coup d'etát of April 1964, characterized by the use of straightforward authoritarianism as a means of resolving the conflict and retaining public resources in the hands of the elite (LAMOUNIER, 1968, pp. 20-21).

Once in the United States, however, Lamounier (1974b) got in touch with the theories and models of authoritarianism formulated by Juan Linz, and abandoned the category of conservatism. Linz emphasized the specificity of authoritarian regimes, such as Salazarism and Francoism, in relation to totalitarian ones such as Bolshevism, fascism and Nazism:

[Authoritarian regimes are] political systems in which there is a certain degree of pluralism, but which is limited and not responsible; where there is no elaborate and coherent ideology, but rather a characteristic mentality; which has no political mobilization, either extensive or intensive, except at certain moments of its development; and in which a leader (or occasionally a small group) exercises power within limits which, although formally illdefined, are in fact quite predictable (see LAMOUNIER, 1974b, p. 70).

Linz's work would have a central influence on the doctoral thesis of Lamounier (1974b), entitled 'Ideology and authoritarian regimes: theoretical perspectives and a study of the Brazilian case". In it, he endorsed and applied the authoritarian model described by Linz, except for the category of ideology, which the latter believed was 
exclusive to totalitarian regimes. Refusing to conform, in 'Ideologia em regimes autoritários: uma crítica a Juan J. Linz' (Ideology in authoritarian regimes: a critique of Juan J. Linz) (1974a), the young doctor would criticize his mentor's perspective as abstract and ethnocentric, leading him to consider the thought of the Iberian and IberoAmerican countries as lacking originality or intellectual interest. In this article he denounced the tendency of intellectuals in authoritarian countries (including Linz himself) to believe that, because they were peripheral, their countries did not have a true history of ideas; that their intellectual production would be marked by an "absence of connection between 'theory' and 'practice', between ideas and real behavior", which would reduce it to pure "second-class imitation" (LAMOUNIER, 1974a, pp. 88-89). In order to understand the specific dynamics of late industrialization in societies ruled by authoritarian regimes, it was necessary to legitimize the study of their intellectual histories. Only then could it be recognized that in such societies authoritarian legitimacy was built on a "state ideology" elaborated by intellectuals and endowed with emotional rather than rational elements (LAMOUNIER, 1974a, p. 77). Whereas 'classical bourgeois ideology' legitimized social organization via the market, asserting capitalist individualism as the natural form of society, things happened differently in late industrialization societies:

[In these societies, dominant ideologies] represent a diverse constellation of representations and argumentative resources. On the one hand, they have a strong, if not dominant, 'statist' element, which, it seems to me, must be understood basically in terms of the specifically political conditions of peripheral capitalist development. On the other hand, the economic legitimation of this development (...) is less necessary, or necessary in a very different way (LAMOUNIER, 1974a, p. 81).

Thus, in peripheral capitalist countries, populations would not be guided by a market-centered bourgeois ideology, but by a demobilizing statist ideology whose purpose was to convince civil society of the need for authoritarian rule.

State ideology and political representation: formalism as the cure for authoritarianism (1974-1981)

Shortly after, invited by Boris Fausto to write about the political thought of the First Republic in the collection História da Civilização Brasileira (A History of Brazilian Civilization), Lamounier elaborated a summary of the argument of his thesis in his 
chapter Formação de um pensamento político autoritário na Primeira República: uma interpretação (The formation of authoritarian political thought in the First Republic: an interpretation' (2006). According to Lamounier, although works partially fitting the description went back to the Empire, it was only in the First Republic, with Alberto Torres, Oliveira Vianna, Azevedo Amaral and Francisco Campos, that the statist tradition would acquire the specific configuration of an "authoritarian ideology" (LAMOUNIER, 2006, p. 370). These were authors of great importance insofar as their works had provided the main ideological basis on which both the 'Estado Novo' and the military regime, then still in full force, rested. The 'authoritarian ideology of the state', was, in turn, used as a theoretical model from which Lamounier set out to organize his history of authoritarian ideas, which had as its object a canon that he systematized through an "effort of global interpretation of a given author, period or current of thought" (LAMOUNIER, 2006, p. 375).

According to Lamounier, prior to his own interpretation, four models had been produced to understand the intellectuals of the First Republic by what he called "realist critics" (LAMOUNIER, 2006, p. 375). Three of them had already been correctly identified by Wanderley Guilherme dos Santos. The first was the 'institutional-scientific', which had emerged from the institutionalization of university teaching and research activities in social sciences, and whose greatest exponent was Florestan Fernandes. Here, Lamounier amplified the criticisms made by Santos, claiming that proponents of this model confused social theory with political thought and were unable to understand the authors in their context or to examine them systematically. The second model was the 'historicist-nationalist', whose paradigm rested upon the supposedly correct version of reality that could be accessed via a nationalistic prism. The greatest exponent of this model was "Guerreiro Ramos, author, it must be said, of some of the best essays on the history of political ideas in Brazil" (LAMOUNIER, 2006, p. 376). The major problem of this model was "in the definition of the theoretical status of the error, that is, of the partiality or ideological character of the past intellectual production. These were interpreted as resulting from the emergence of an objective nationalistic consciousness, small flares of light that stand out against a shadowy background of ideology, of colonial aristocratic caricature" (LAMOUNIER, 2006, p. 378). The third model criticized by Bolívar Lamounier was the 'classicist' who confined himself to "taking an author or a group of authors and adjusting to the manifest content of his works to classic - that is, 
19th century Europeans - models of 'conservative' thinking, petty bourgeois', 'reactionary', etc." (LAMOUNIER, 2006, p. 378). In this scheme, "positions vary from the mechanical application of classical schemas to the description of class structure and the denial of its applicability, through allusions to the 'immaturity' or 'incipience' of social classes in Brazil's social formation" (LAMOUNIER, 2006, p. 379). This was not to say that the method should be completely discarded, since understanding the contents of ideological production became clearer in the context of its relations with social classes. But it should, of course, be softened.

The fourth and final model Lamounier criticized was that which he called 'enlightened authoritarianism'. Here began the criticisms of Santos's own interpretation, the latter seen as the preeminent representative of this model. The hypothesis of 'instrumental authoritarianism' clashed head-on with Lamounier's own research and, more broadly, with the assumptions of Linz's theory (SANTOS, 1978, pp. 224-255). Lamounier here accused his colleague of naturalizing arguments of enlightened authoritarianism, proper to the opponents of the "Enlightenment and the abstract constitutionalism of French liberalism of the eighteenth century" (LAMOUNIER, 2006, p. 381). In Brazil, this model would be linked to "the nationalist historicism of the 1950s", with its "tendency to automatically identify the strengthening of public power with development and social progress" (LAMOUNIER, 2006, p. 383). Santos was thus accused of reproducing "Oliveira Vianna's own self-image of authoritarian thought, which, besides glorifying the conservative tradition of the Empire, declared itself the monopoly holder of political realism and good intentions for the nation" (LAMOUNIER, 2006, p. 382). Interpretive hypotheses such as 'organic idealism', 'critical pragmatism' and instrumental authoritarianism were expressions of a state ideology, defined as "an ideological system oriented towards conceptualizing and legitimizing the authority of the state as the tutelary principle of society" (LAMOUNIER, 2006, p. 384).

[Within this model] techno-intellectuals embedded in the apparatus of the State form a very special elite, driven by altruistic intentions, a vision with grand horizons and an incorporeal objectivity. Eminently realistic, it favors a pragmatic, enlightened, temporary authoritarianism whose true and hidden objective often escapes even its beneficiaries (LAMOUNIER, 2006, p. 383).

For Lamounier, it was a "worldview in which all representations leading to the notion of a "political market" are driven away, exorcized and replaced with 
representations based on the principle of authority and an assumption of shared values" (LAMOUNIER, 2006, p. 385). The ideology of the state was opposed to the liberal, market-centered ideological matrix which had guided the formation of capitalism and the modernization of the core countries. Although liberalism presupposed a representation of the state, it did not give it a factual and ethical priority; instead, its central image, or integrating principle, was society, in which the individual figured as the source of political legitimacy, and the market as the basis of economic relations. The intention of state ideology was to "domesticate the market, and in particular, the market principle that is active in political relations" (LAMOUNIER, 2006, p. 385). To this end, against 'classical liberal thought', statist ideology would bring together all antiEnlightenment, conservative, reactionary and authoritarian formulations to oppose the modernization of the economy, society, and the political institutions and language characteristic of liberal democracy. The political model of state ideology had eight characteristics: 01 . The predominance of the state principle over the market principle; 02. An organic-corporate vision of society; 03. Technocratic objectivism; 04. A paternalistic-authoritarian vision of social conflict; 05. Disorganization of civil society; 06. Political demobilization; 07. Altruistic elitism and a willingness to carry out coups d'etát; 08. An image of the state as a benevolent and responsible entity, "guardian and vital force of an equally benevolent, 'cordial' and cooperative society" (LAMOUNIER, 2006, p. 400).

In A representação política: a importância de certos formalismos (Political representation: the importance of certain formalisms) (1981), Lamounier offered additional institutionalist arguments to his interpretation. Despite the differences internal to his conceptions of representation, he stated that no political ideology except liberalism had formulated an alternative to representation that was capable of preserving individual freedoms and guarantees. The democratic dynamic of extending rights, following the steps outlined by Marshall, emerges from a broad debate on the best form of representation. In other words, there would be no modern democracy without some conception of representation capable of institutionally channeling social demands for citizenship and recognition. Authoritarians' dissatisfaction with the supposed formalism of representative institutions undermined the development of democracy, because it favored plebiscitary or corporate alternatives that ended up rejecting it (LAMOUNIER, 1981, p. 234). Despite patrimonialism and other obstacles 
identified by authoritarians impeding the proper functioning of representative institutions, the truth was that, in the long run, Brazilian society exhibited a real development towards democracy. That is to say, the workings of representative institutions had contributed effectively to overcoming problems, as urbanization and literacy rates increased:

Within this order of ideas, I propose that the misconception of the so-called realist critics of the liberal institutions of the Empire and the Republic consisted in seeking in them an idea of representation that could not actually occur at that moment, and in not recognizing what actually occurred and was perhaps the key to the whole political-institutional problem (LAMOUNIER, 1981, p. 239).

It is in this sense that Lamounier condemned the notion of instrumental authoritarianism: the argument that backwardness justified state tutelage obscured the democratic advances secured by Brazilian society, always despised by its enemies as insufficient in the face of an idealized — and still unattainable — standard: "A discourse that imprisons the problem of representation in the rigid and impoverished contrast between the legal Brazil and the real Brazil (...) has formed between us. It is as if we say: the representation between us will always be a farce, since it was never anything else" (LAMOUNIER, 1981, p. 237). Authoritarians such as Alberto Torres and Oliveira Vianna were never truly instrumentalist because they ignored the historical conditions that had produced the maturation of the representative system, preferring the tutelage of society by a state led by a technocracy which they judged to be superior from an ethno-cognitive point of view (LAMOUNIER, 1981, p. 244). The realists, then, were not in fact the authoritarians, but, rather, the liberals. The authoritarian belief that it would be possible to centralize a country with a low level of urbanization and structural weakness in transport and tax collection seemed to him to be incredibly naive (LAMOUNIER, 1981, p. 241). Meanwhile, liberalism was realistic in recognizing the need for classical representative institutions to advance the democratic model. This explains the centrality of Ruy Barbosa to the 'canon' of liberal Brazilian authors, given that he, like few others, understood the intrinsic advantages to preserving the republican mechanisms of participation. 
Institutions versus culture: Ruy Barbosa as a precursor of Brazilian institutionalism (1991-1999)

Lamounier's next writings on Brazilian thought were produced in the 1990s, in a very different context to the previous period. In the field of political science, the collapse of Iberian and Latin American dictatorships shifted the focus of research from the question of authoritarianism to the construction and proper functioning of democracy. The fall of the Berlin Wall had sharpened critiques of the 'Varguista' state model, denounced as being incompatible with democracy because of its heavy intervention in both society and the market. From an institutional point of view, there was also liberal criticism of presidentialism and proportional voting, both confirmed by the 1988 Constitution, and considerable mobilization of liberals around the prospect of an extensive revision of the constitution in 1993, when there was also to be a plebiscite on the system of government. Lamounier was probably the political scientist most engaged in the campaign to change the system of government, writing two important texts to justify his position. The first was published in a collection he edited himself, A Opção Parlamentarista, (The Parliamentary Option) (1991), which brought together prestigious international authors such as Juan Linz, Arendt Lijphart and Arturo Valenzuela. In Brasil: rumo ao parlamentarismo (Brazil: towards parliamentarism) (1991), Lamounier rejected the argument that Brazilian political culture militated against the alternative system of government, and argued that the question should be viewed from the angle of neo-institutionalism, which would work "with governmental structures themselves, not with cultural determinants"(LAMOUNIER, 1991, p. 17). Institutions were capable of generating beneficial or pernicious effects on freedom by themselves and should be evaluated as such. After emphasizing the supposed failure of Brazilian presidentialism, Lamounier suggested that this tradition would not be as dense, nor the parliamentary aspiration as rarefied as was presumed (LAMOUNIER, 1991, p. 60). Although the plebiscite was won by the presidentialists, the 1994 elections did not lead a socialist to the presidency, but rather a liberal, Ferrnando Henrique Cardoso, who continued the agenda of economic liberalization and privatization begun by Fernando Collor de Mello.

It was in this context that the then President of the Fundação Casa de Ruy Barbosa (Ruy Barbosa Foundation), Mario Brockman Machado, commissioned Lamounier to write the essay Ruy Barbosa e a construção institucional da democracia 
brasileira (Ruy Barbosa and the institutional construction of Brazilian democracy) (1999). Here he presented, for the first time, a more detailed account of the tradition counterpoised to authoritarian thought: that of a cosmopolitan liberalism, committed to the defense of democratic institutions. Just as Wanderley Guilherme dos Santos had rehabilitated Oliveira Vianna as paradigmatic intellectual of an 'instrumental authoritarianism' that could be read to the left by the socialists, Lamounier rehabilitated Ruy Barbosa, the author who had been the most vilified for his 'doctrinal liberalism' by the authoritarians. To do so, he proposed "a reflection on the concept of institutional construction, clearing away the ideological rubble that had accumulated over it and definitively banishing the merely formalist and jurisdicist aura that surrounded it'" (LAMOUNIER, 1999, pp. 53-54). From North American institutionalism, Lamounier denounced as anachronistic approaches that condemned Ruy Barbosa's supposed formalism: from Lipset to Linz, passing through Huntington, Dahl, Nohlen and Lipjhart, political science had abandoned "the old determinism of 'cultural complexes', positivist 'phases', and the surreptitious, so-called 'modernization theory'" to move ever closer to "institutional construction" (LAMOUNIER, 1999, pp. 53-54). According to these political scientists, "stable and robust democracies" are "the historical result of two simultaneous and equally indispensable vectors: that of the continuous improvement of living conditions, reducing, as much as possible, income and wealth inequalities, on the one hand, and of persistent and progressive political-institutional action, on the other "(LAMOUNIER, 1999, p. 116). Lamounier thus emphasized the importance of "crafting, from which every political institution worthy of the name is a historically cumulative result" (LAMOUNIER, 1999, p. 53). Although the autonomy of institutions was not absolute, there was no doubt "that their institutionalization is a key issue in the evolution of what we now understand as representative democracy" (LAMOUNIER, 1999, p. 111).

From this perspective, Lamounier once again condemned the Brazilian authoritarian tradition that resulted from three currents: positivism, Marxism, and culturalism. Guided by the ideal of republican dictatorship, which echoed through the works of Alberto Torres, Oliveira Vianna, Francisco Campos and Azevedo Amaral, positivism underpinned authoritarianism in the first half of the century, later giving way to Soviet-inspired Marxism. The culturalism of the early days of social science had also contributed to authoritarianism by lending "a supposedly scientific legitimacy to an 
authoritarian project that was gradually fleshed out before gaining ascendancy with the Estado Novo" (LAMOUNIER, 1999, p. 56). By this time, Lamounier was reprimanding Oliveira Vianna as "the anti-Ruy 'par excellence'" (LAMOUNIER, 1999, p. 58); a conservative who, based on his belief in the immutability of cultural complexes, concluded that Brazilian society could only achieve democracy after fulfilling certain cultural or socioeconomic prerequisites (LAMOUNIER, 1999, p. 63). Nothing could be more different from Ruy, with his liberal and progressive stance, open to the improvement of institutions through the incremental influence of social dynamics:

For Oliveira Vianna, the social and political ills of colonization were to be understood as 'culture', which, for him, was equivalent to destiny. For Ruy Barbosa, on the contrary, they were the inevitable environment for political action and the raw material on which work on institutional construction would take place: a terribly adverse environment, no doubt, but not as adverse as when adding to it the definitive sacrifice of the freedom (LAMOUNIER, 1999, p. 60).

He had realized that "institutional construction was the alpha and omega" of democracy and, imbued with that certainty, decided the Republic should be civically shaken out of its lethargy when the regime accommodated itself "to very low standards of performance" (LAMOUNIER, 1999, pp. 112-113). Barbosa's institutional imagination, expressed in the 1891 Constitution and his later struggle for the authenticity of the democratic regime, was linked to the growing political influence of progressive middleclass sectors, led by tribunes like himself, who were politicians, jurists and intellectuals: "There will always be deliberate action by individuals and groups with a view to the formation of democracy; is that crafting in which politicians, jurists and intellectuals normally have a predominant role, paving the way for the progressive political participation of the majority of citizens" (LAMOUNIER, 1999, p. 64). The middle class was considered by Lamounier to be a kind of universal class, that is, as the collective actor best identified with the ideals of democracy. For this reason, the status of hero of the middle class, not only did not remove from Barbosa the vocation of universality, it reinforced it. For all this, the alternative to authoritarianism proposed by Barbosa was the most correct one. It was based on a form of presidentialism similar to that of the United States, which maintained a rational and stable parliamentarism, as well as an autonomous judiciary, a vigorous federation and broad municipal autonomy: "The institutional foresight of Ruy Barbosa is far more adequate than that of his critics, if we 
evaluate it in terms of our political evolution throughout the whole century, and also in relation to what contemporary political science has been saying about the historical process of the development and consolidation of democracies" (LAMOUNIER, 1999, p. 115).

\section{Intellectuals, liberalism e capitalism: new definitions (2014-2016)}

Fifteen years after his essay on Ruy Barbosa, Lamounier published two books dedicated to discussing the relation and role of intellectuals in the production of thought: Tribunos, profetas e sacerdotes (Tribunes, prophets and priests) (2014) and Liberais e antiliberais (Liberals and anti-liberals) (2016). He believes that ideas matter and that intellectuals play an important role in influencing "the evolution of the political system in a liberal or anti-liberal direction" (LAMOUNIER, 2014, p. 14). Based on this premise he constructed a typology of intellectuals who played key roles in the construction of ideologies and defense of certain regimes throughout the twentieth century. The first was that of the 'tribune', who was driven by a desire to intervene in reality in the name of an ideal, acting in the defense of a group, person or institution, such as Emile Zola in the Dreyfuss affair (LAMOUNIER, 2014, p. 25). The 'prophet', meanwhile, was a visionary bearing a message of salvation that pointed towards the redemption and transformation of men. Rousseau is mentioned as paradigmatic of the "secular prophets" in seeking to reconcile humanity with itself (LAMOUNIER, 2014, p. 34); meanwhile Marx was the prophet of a classless society; and Comte, that of "a political system without politics" (LAMOUNIER, 2014, p. 142). The third type, the 'priest', was responsible for knowing and observing scriptures considered sacred, preserving the integrity and correction of orthodoxy. Carl Schmitt and Giovanni Gentile were the priests of fascist holism in Germany and Italy, respectively. Lenin was a prophet before the Russian Revolution and a priest after it. As can be seen, the tribune is presented as a positive type of intellectual, because he is committed to the defense of liberalism and, by extension, of democracy. Meanwhile, the prophet and the priest are the negative, anti-liberal types because their dogmatism would lead them to arrogate to themselves the knowledge of the true identity of men and the meaning of their historical action. In short, the twentieth-century 'drama' had ended in the permanent conflict between the 'tribune', the liberal apostle of a 'common humanity', and 'priests' and 'prophets' representing authoritarian and totalitarian ideologies, who subordinated the 
individual to 'totalities' such as the nation, the people or the proletariat (LAMOUNIER, 2014, p. 12).

By restating the dichotomy that characterized his classification of Brazilian thought, though here on a larger scale, Lamounier sought to narrow its positive pole, making liberalism, democracy and market inseparable: "The term liberalism is consubstantial with democracy; we can even say, with some redundancy, that it is the political theory of liberal, or representative, democracy" (LAMOUNIER, 2014, p. 13). In his view, the liberal ideology was characterized by "the recognition of the public and the private as distinct and equally legitimate spheres - including the private economic sector and the great variety of associations subsumed within the notion of pluralism" (LAMOUNIER, 2014, p. 13). Thus, if liberalism is defined as the "ideology of capitalism and democracy" (LAMOUNIER, 2014, p. 17), anti-liberalism is conceptualized as its negation, as constituting "the philosophical doctrines and political action that oppose it", that is, the fascism on the right and Marxism on the left, with "their respective ramifications and derivations." Anti-liberal doctrines are characterized by epistemological and moral holism and authoritarianism stemming from antiinstitutionalism, which in turn stems from the deification of the state, the leader and the party (LAMOUNIER, 2014, p. 13). In order to understand the dynamics of how such intellectuals have acted historically, Lamounier adopts a scheme that identifies the development of liberal democracy across three successive stages: the construction of the State, industrialization and thematization of democracy (LAMOUNIER, 2014, p. 17). By shifting his typology to the examination of the intellectuals who have influenced Brazilian thought, instead of associating the process of national construction with the Empire, Lamounier takes as his starting point the First Republic, arguing that the 1891 Constitution "maintained the liberal spirit of the Monarchical Charter of 1824" (LAMOUNIER, 2014, p. 134). This auspicious beginning, at the hands of the liberal tradition of the Empire represented by Ruy Barbosa, was counteracted by the intellectual emergence of "protofascism" (LAMOUNIER, 2014, p. 135), an anti-liberal current, inaugurated by Alberto Torres, that would deny the autonomy of the individual and of society in relation to the State.

The primacy Lamounier attributed to Torres in the production of this supposed protofascism does not prevent him from preferring to focus, once again, on the figure of Oliveira Vianna, whom he refers to as the anti-liberal priest 'par excellence', a true 'bête 
noire' whose work epitomized all the characteristics of anti-liberalism: organicist sociologism; anti-individualist holism; a belief in the state as the protagonist of modernization; and the rejection of liberalism as utopian (LAMOUNIER, 2014, p. 180). At this point, Bolívar cannot resist once again attacking the position of his old adversary, Wanderley Guilherme dos Santos. The assumption that the latter was a pragmatic and provisional authoritarian had to be false, Bolívar claimed, as in his entire body of work there was nothing to indicate the "instrumentality" of dictatorship, which he preached as a step towards democracy (LAMOUNIER, 2014, p. 196). The very conception of instrumental authoritarianism destroyed the possibility of an autonomous organization of society. The second round between liberalism and authoritarianism occurred around the model of industrialization in the 1950s. The new avatar of anti-liberalism was the national-developmentalist movement, which brought together remnants of Vargas-style fascism, communism, and integralism to advocate the "strong intervention of the State, both business and regulatory, in the economy" (LAMOUNIER, 2014, p. 140). Among the main representatives of the new antidemocratic authoritarianism, examples of the 'priest' intellectual model, were the intellectuals of the Instituto Superior de Estudos Brasileiros (ISEB) - Celso Furtado, Hélio Jaguaribe, Guerreiro Ramos and Álvaro Vieira Pinto - and those around the Revista Civilização Brasileira, who rejected the capitalist model, understood as the space of individual initiative and the market. Putting an end to disputes over different possible models of modernization and democracy, the coup of 1964 had brought the intellectuals' focus back to the nature of the dictatorial regime, thereafter devoting itself to investigating how military government could act to promote the expansion of capitalism in the country. Driven by the spread of Marxism in academia, anti-liberal alternatives to democracy and the market returned to the scene, endangering the third stage of the development of democracy, which was that of its explicit thematization from the 1970s onwards.

Lamounier's concern with exorcising the historical tendency of the Brazilian intelligentsia towards anti-liberalism culminates in an effort to redeem the country's liberal tradition. The faith that intellectuals like Ruy Barbosa invested in representative institutions derived from a clear-headed perception that only the promotion of free expression of interests in both the market and society could promote Brazilian development in a positive direction. The novelty here was the inclusion of a new exemplary liberal intellectual, Sergio Buarque de Holanda, whose work proved how far 
the Iberian origin of Brazilian society had produced enormous obstacles to the constitution of a "truly legal and impersonal state" (LAMOUNIER, 2016, p. 209). Barbosa and Holanda served as models for all those who, against the authoritarian tendency inherited from colonization, sought to contribute to the construction of a truly democratic political culture in Brazil.

An overall assessment of Bolívar Lamounier's interpretation and contribution: strengths and weaknesses

The contribution of Bolívar Lamounier's work to Brazilian political thought should not be underestimated. Firstly, it made it a respectable object and discipline of study. By criticizing abstract and ethnocentric conceptions that restricted interest in political theory to that produced in the core countries, he highlighted the importance of studying intellectual history to understand the specific dynamics of late industrializing societies. He denounced the ethnocentric tendency of the latter's intellectuals in believing in the heuristic value of such theory, dismissing it as an ideological farce when compared to the supposed organicity and coherence operating in core countries. He described the typical mechanism via which they were produced, which, on the one hand, applied "the whole system of political and social concepts" to the study of "Brazilian history and society", while remaining "in tune with the "widest-ranging trends on the world stage" (LAMOUNIER, 1974, p. 385). The study of Brazilian thought should understand how individuals or groups acted as agents, defined interests and projected themselves into new horizons of social coexistence. In this way, he revealed how intellectuals' ideological formulations invoked diverse visions of future, pointing to different alternatives for the process of capitalist modernization and the consolidation of democratic institutions in Brazil.

But Lamounier also contributed to freeing the study of Brazilian thought from the economistic and sociological approached that dominated in academia, defending the relative autonomy of politics from the economy. He criticized contemporary Marxism's lack of sophistication, limited to the production of "schematic analyzes in which the agents of historical events appear as carriers of universal consciousness who, therefore, can be known in advance" and who, looking at Brazilian intellectuals, identified precisely a "lack of these universal contents" (LAMOUNIER, 1974, pp. 372-373). He opposed the kind of socio-literary approach adopted by Antonio Cândido, insisting that an authors' 
choice of study should be determined by their relevance to the formation of ideologies, and to the interpretation of political processes and institutions. Especially relevant was his concern with preventing a repetition, in political science, of the scientific rhetoric that in the case of sociology had caused a rupture with lines of thought that had preceded academic institutionalization. It was in this way that, in his 1980 survey of the nascent field of political science, Bolívar attributed its rapid and successful development "to the existence of an important tradition of political thought, prior to the convulsions of economic growth and urbanization of this century, and even to the establishment of the first universities." Not only was there "remarkable continuity" between traditional and contemporary political science, but it was the prestige of the former that legitimized the development of the latter (LAMOUNIER, 1982, pp. 407-409).

However, it is in the study of intellectual traditions that Lamounier's contribution can most clearly be seen: of having redeemed the study of the liberal tradition, which, since the 1920s, had carried the stigma of alienation imbued by nationalist scholars, such as Oliveira Vianna, Guerreiro Ramos and Wanderley Guilherme dos Santos. He was the first political scientist to show that, for authors like Tavares Bastos, Ruy Barbosa, or Assis Brasil, liberalism's famous idealism functioned as a critical theory of reality, designed to model reality while departing from the ideal of freedom. Liberal idealism, far from dispensing with realist diagnoses, provided its advocates with a rhetoric of indignation designed to mobilize public opinion through parliamentary, journalistic, or judicial platforms to move it towards freer and fairer standards of collective life. In late-industrializing societies, as was the case in Brazil in particular, and Latin America generally, it was strategic to resort to institutional engineering on a larger scale. This was a crucial instrument that would induce behavior change in the population towards supposedly more civilized standards, by instilling values proper to liberal and democratic political culture, such as a love of freedom, individual responsibility, work ethic, valuing civic life, etc. It was by following the "real road of probing political morality" (BARBOSA, 1981, p. 20) that, according to Ruy Barbosa, the constitution could go beyond the limits of formalism and, when it became effective, transform Brazil into "a republic where republican life was intensely saturated with the spirit of its institutions" (BARBOSA, 1981, p. 21). This framework did not indicate that liberals were alienated from Brazil's reality, including in terms of their knowledge of its political culture, which they understood as being backward. Rather, 
what distinguished them from the so-called 'authoritarians' was their greater optimism, stemming from a cosmopolitan philosophy of history as progress, which made them less pessimistic about the resilience of colonial heritage.

However, not everything in Lamounier's interpretation can be assessed so positively. In particular, we can detect a certain analytical impoverishment in his more recent analyzes, characterized by his efforts to convince the public that liberalism is the only ideology that is both truly 'realist' and beneficial for Brazil. His gradual distancing from academia, alongside a growing militancy among parties like the PSDB and think tanks like the Instituto Millenium (Millennium Institute), have made it virtually impossible to distinguish between Bolívar the academic, engaged in the objective study of ideologies, and Bolívar the public intellectual, committed to influencing the political conversation. This loss of sophistication can be measured in the first place by a tendency to present an increasingly sharp — we might even say, Manichean — dichotomy between the positive pole of liberalism, associated with the market and democracy, and the negative pole of 'anti-liberalism' or 'authoritarianism', bringing together disparate ideologies such as socialism, fascism and conservatism. This dichotomy, we should note, is presented through explanatory schemas that are unconvincing, both historically and conceptually. Secondly, it is clear that his analysis has failed to keep up with developments in the literature on ideology and political thought in recent decades. This can be seen by a quick glance at the bibliographies of his latest books, which include few references published after 1980. As far as the object of this article is concerned, Lamounier does not even engage with the most influential Brazilian interpretation of the last ten years, formulated by Gildo Marçal Brandão (2005). He insists on exclusively discussing Santos, as if the current state of the field were still the same as thirty years ago.

These issues explain a number of shortcomings in his analyses that have undermined claims made in his earlier works. Here we will mention the most important of these. The first concerns a growing tendency to offer ethnocentric simplifications similar to those he had criticized in Linz's work in 1974. Although Lamounier stresses its importance, Brazilian thought tends to be presented as a mere echo of the ideologies produced elsewhere, and as no longer having the peculiarities he had previously implied. He treats human nature as if it were the same everywhere and the historical process a kind of universalistic evolutionism, ignoring the fact that the distinct 
perceptions that the intellectuals of backward countries hold about their place in the world also affects the ways in which they absorb foreign ideologies. Likewise, there is a problem of analytic bias. Since, according to the interpretation embraced by Lamounier, Brazil was born lopsided, patrimonialist and authoritarian due to Iberian colonization, the only ideology that could be of any benefit to it is liberalism, whose ideals and institutions have the power to embed the market and representative democratic institutions. In sum, Lamounier's analyses as a student of Brazilian political thought became increasingly consistent with those formulated by the liberal authors he studied, as if the subject of this knowledge were dissolved into its object.

Another negative point lies in the desire to present liberalism as the only true and desirable ideology, presenting all others as built around obscurantist ideals. Lamounier strives to erase or dissolve the nuances and differences between socialist and conservative ideologies, much like his own ultimate approximation to liberalism, thus drawing an absolute dichotomy based on the simple argument that they "oppose each other to the same degree as to democracy and the conception of freedom" (LAMOUNIER, 2016, p. 16). This narrow explanatory model seems to have been drawn from Zeev Sternhell, whose studies on the origins of fascism are rooted in a reductionist interpretation of the Enlightenment and, by extension, the 'Anti-Enlightenment' (STERNHELL, 1978, 1994, 2006). However, it is difficult to believe that anti-liberals such as Rousseau, Hegel, Marx, and even Comte are not, to some extent, equally legitimate heirs of Enlightenment as Montesquieu, Kant, Tocqueville, or Stuart Mill. Historians such as Franco Venturi and John Pocock have warned us against this simplistic idea of a single Enlightenment for decades, drawing attention not only to its ideological complexity but also to its distinct national traditions (POCOCK, 2003; VENTURI and FLORENZANO, 2003). For these reasons, categories such as 'Anti-Enlightenment', 'anti-liberalism', or 'protofascism', through which Lamounier attempts to approach disparate ideologies such as socialism, fascism, or positivism, as if they were variations of the same phenomena or enemy, are unable to shed adequate light on the problem. 'Protofascism', in particular, is a category whose explanatory potential in political science is as meager as that of 'pre-Socratic' in philosophy. That is without mentioning the implicit, implausible, teleological assumption that certain ideological phenomena, such as positivism, are necessarily destined to lead to others, such as fascism. 
But the attempt to create an absolute dichotomy between ideologies does not only impede the analysis of socialism and conservatism, but also of liberalism itself, steadily reducing it to within the narrow limits of representative institutions and the free market. This definition may make some sense when applied to more remote liberals, such as Paine or Constant, or contemporaries, like Fukuyama. But it does not apply to many other liberals, especially those who lived through the twentieth century. It is well known that the emergence of democracy at the end of the nineteenth century provoked a crisis in classical liberalism, which could only be resolved through the separation of its political and economic aspects. Liberal movements such as American progressivism, the new English liberalism, and French solidarism began to recognize the necessity of state intervention in the socio-economic sphere in order to guarantee to the greatest number possible the level of equality necessary for exercising their freedom (BELLAMY, 1994; BENTLEY, 1983; McGERR, 2003; MERQUIOR, 1991). After World War I, the gap between political liberalism and free markets only increased: not only were social democracies established in the principal countries of Western Europe, but politically liberal states such as the United States and Great Britain rejected economic liberalism, respectively enshrining economic interventionism through the New Deal and, after 1945, the Beveridge Plan (GAUCHET, 2010). Indeed, after World War II, under the primacy of Keynesianism, Karl Mannheim's works, such as Freedom, Power and Democratic Planning, firmly established the belief that liberal democracy could not be sustained without some kind of economic planning (MANNHEIM, 1972). In Brazil, Ruy Barbosa acknowledged the need to permit state intervention in the socioeconomic domain in 1919 in his famous speech A Questão Social e Política no Brasil (The Social and Political Question in Brazil) (1960). The most conspicuous liberals of the 1940s and 1950s, such as Afonso Arinos, Aliomar Baleeiro, Prado Kelly, and Bilac Pinto, while favoring free entrepreneurship to the excesses of statism, also rejected noninterventionism as anachronistic (FRANCO, 1961, p. 180). The only liberal thinker who defended a complete free market against state intervention by that point was Eugênio Gudin, an economist who was avowedly not a democrat (ALMEIDA and SCALÉRCIO, 2017).

The lack of rigor in his definition of ideology, his explicit adherence to one of these in particular, the effort to reduce his adversaries to the condition of a single category, and his narrow concept of liberalism also hindered Bolívar's analysis of the 
different traditions of Brazilian political thought. The identification of authoritarianism with culturalism, for example, is debatable, appearing more applicable to another line of authors: that of classical conservatives such as José de Alencar, Eduardo Prado or Gilberto Freyre, who defended Brazil's Iberian and Catholic social formation (LYNCH, 2017b). Here the distinction between pure and instrumental authoritarians made by Wanderley Guilherme dos Santos points out that Alberto Torres and Oliveira Vianna, hoping to use the state to modernize the country, did not endorse the culturalism of these authors. Like Euclides da Cunha, Torres believed that Brazil had no national culture and should be politically oriented by the study of its physical and human geography. Instead of defending culture, he called for, a "work of regeneration of institutions, customs, traditions and tendencies" (TORRES, 1981, p. 64; 1914, p. 244). Despite his greater ambiguity on the subject, Vianna was also not enthusiastic about culturalism, claiming that culture did not supersede the individual as a force of social life and progress. He dedicated an entire chapter of Instituições Políticas Brasileiras (Brazilian Political Institutions) (first published in 1949) to criticizing those who, like Gilberto Freyre, believed that culture was "an omnipresent and omnipotent entity, an exclusive explainer of the formation of man and of civilization" (VIANNA, 1974, p. 48). Lamounier's explanatory scheme also falls short with respect to Guerreiro Ramos, who is identified as an 'ISEBian' priest, that is: second-generation authoritarian. In 1955, he openly condemned all works, including those of Sérgio Buarque de Holanda, that deployed culturalist explanations, arguing that categories such as 'national character', 'soul', 'spirit', 'vocation', 'race' and 'cordiality' were scientifically dubious (RAMOS, 1995, p. 185). On the other hand, the defense of market liberalism, condoned by Lamounier, did not always serve political ends, with some authoritarians also openly supportive.

Finally, the classification of authors such as Torres and as 'authoritarian' itself is inappropriate, if by that we understand the term to mean anything more than condemnation of the minimal state of the nineteenth century. Contrary to Lamounier's suggestion, the new 'authoritarian' state which they defended not only was not necessarily dictatorial in character, but was also included aspects more closely related to liberalism than he recognized, when their works are interpreted in the context of contemporary forms of liberalism, such as American progressivism or Christian democracy. In the same way, both shared with liberals like Ruy Barbosa an obsessive concern with guaranteeing the civil rights of the population against arbitrary executive 
power, through a judiciary reinforced by guarantees of stability, steadfastness and vitality (TORRES, 1914, p. 81; VIANNA, 1930, p. 45; 1974, p. 164). Torres not only endorsed Barbosa's far-reaching interpretation for granting habeas corpus in the face of violence, coercion, abuse of power or illegality by the state. He was the first to propose the creation of an additional guarantee: the 'mandado de garantia' (guarantee warrant), which twenty years later was created with the name 'mandado de segurança' (security warrant) (TORRES, 1914, p. 295). Oliveira Vianna's judicialism, which included an enthusiastic support for constitutional jurisdiction as a means of controlling executive power in the defense of civil rights, was greater than that of Torres himself. The aim of guaranteeing the effectiveness of civil rights enshrined in the constitution, including the substantive widening of access to the justice system, seems to us incompatible with alleged defense of 'dictatorial regimes', affirmed by Bolívar. This point is more generally highlighted by the presence of important liberal elements in his writings (FAUSTO, 2001, pp. 70-73), evident, for example, in its explicit praise for Ruy Barbosa's judicialism:

\begin{abstract}
Understanding the preeminent importance of the Judiciary in our country and in our democracy; exalting its role almost to the point of sublimating it; placing this power beyond the reach of subordination by and dependence on executives and parliaments, always partisan and divided - this is Barbosa's greatest glory. Having established this principle in Brazil is such a far-reaching achievement that it overshadows even his doctrine of habeas corpus and its importance as a guarantee of personal freedom (VIANNA, 1999, p. 504).
\end{abstract}

In the same vein, much of the state intervention advocated by Alberto Torres and Oliveira Vianna came from their understanding, typical of the age in which they lived, that the constitution of a true democracy required the recognition of its social dimension and, consequently, a rejection of the minimal state of nineteenth-century liberalism. Rejecting 'individualism', at the beginning of the twentieth century, meant less the denial of liberalism than its democratization: only state intervention in the socio-economic domain, it was argued, could secure the freedom of the largest number in a sharply unequal society. This is what Torres meant in his nationalist language when he said: "Social democracy, succeeding political democracy, replaces the false task of forming and supporting the 'citizen' (...) with the task of forming and supporting the 'man', the 'individual', the socius of the contemporary nation" (TORRES, 1914, p. 242). Oliveira Vianna also insisted that the nerve centre of the social question was "to create 
the social, economic and spiritual conditions that will allow our vast proletarian masses in the fields and the cities - mainly the fields - the peaceful rise and dispersion of their most well-gifted and capable". Above all these conditions needed to ensure "the millions of Brazilian proletarians - live in their urban slums or in their huts in the 'sertão' - a cheap house or a plot of land" (VIANNA, 1974, pp. 93-94). In short, understood in their own terms, Torres and Vianna were far from being either antidemocratic, or anti-liberal, in opposing the primacy of fundamental rights or the independence of the Judiciary. They saw themselves primarily as defenders of another kind of democracy, which, just because it had not been preached by the old liberals of the eighteenth century due to the greater role it envisaged for the State, was not incompatible with that preached by the new liberals, or social liberals, of Europe and the United States. This was the case of Alberto Torres, in particular.

\section{Conclusion}

The works developed by Bolívar Lamounier in the field of political science, presented and commented upon here, are paradigmatic of a liberal interpretation of Brazilian political thought that seeks to understand it in the light of "liberalism as an organizing principle of political life" (LAMOUNIER, 2016, p. 51). On this basis, it has both positive and negative aspects. On the positive side, it shows the great merit of rehabilitating the liberal intellectual tradition from the opprobrium to which it has traditionally been greeted within 'nationalist' interpretations, that is, as an expression of alienation from national context, referred to pejoratively as 'utopian', 'consular', 'detached', or 'doctrinaire'. Lamounier reveals that the liberals invested their hopes in a process of institutional construction that, through learning, would allow democracy to take root in national soil. The liberal reformists of the First Republic, in particular, believed that in a backward society like Brazil that lacked modern 'political and social content', it would be up to constitutional engineering to create the 'legal and institutional forms' that would allow the country to become modern (RAMOS, 1966; HOLLANDA and COSER, 2016). On the negative side, Lamounier's interpretation can be criticized for committing the same crime of which he had accused others, in the opposite direction. Thus, if he accuses Santos of attributing 'the' self-image of his own authoritarian thought 'à la' Oliveira Vianna, which, in addition to glorifying the conservative tradition of the Empire, proclaimed himself the monopoly holder of 
political realism and good national intentions (LAMOUNIER, 2006, p. 382), Lamounier's interpretation could also be criticized of attributing — to paraphrase the passage above — 'the self-image of liberal thought itself à la Ruy Barbosa, who, in addition to glorifying the liberal tradition of the First Republic, proclaimed himself the monopoly holder of the democratic ideal and good social intentions'. We can conclude from this that a classification is needed which abandons such dichotomous criteria, with its pretense of presenting some ideologies as truer or more desirable than others, and instead to study them as competing and legitimate languages or discourses that dispute hegemony in society from a perceived reality, no matter how different their criteria, values and objectives might be.

Translated by Matthew Richmond

Submitted on June 26, 2017

Approved on December 27, 2017

\section{References}

ALMEIDA, Rodrigo and SCALERCIO, Márcio (2017), Gudin. Rio de Janeiro: Insight. 326 pp..

ARON, Raymond (2002), Paz e guerra entre as nações. Brasília: Editora Universidade de Brasília. 936 pp..

BENTLEY, Michael (1983), The climax of liberal politics: British liberalism in theory and practice, 1868-1918. London: Edward Arnold. 158 pp..

BARBOSA, Ruy (1981), Embaixada em Buenos Aires. Rio de Janeiro: Fundação Casa de Ruy Barbosa. 285 pp..

BARBOSA, Ruy (1960), Escritos e discursos seletos. Rio de Janeiro: Editora José Aguilar. 1.095 pp..

BELLAMY, Richard (1994), Liberalismo e sociedade moderna. São Paulo: Editora UNESP. 467 pp..

BRANDÃO, Gildo Marçal (2005), Linhagens do pensamento político brasileiro. DADOS. Vol. 48, № 02, pp. 231-269.

BURNHAM, James (1943), The Machiavellians: defenders of freedom. Chicago: Gateway Edition. 324 pp..

CARR, Edward Hallett (2001), Vinte anos de crise 1919-1939: uma introdução ao estudo das relações internacionais. Brasília: Editora Universidade de Brasília. 354 pp.. 
CASTIGLIONE, Dario and HAMPSHER-MONK, Iain (ed) (2001), The history of political thought in national context. Cambridge: Cambridge University Press. 313 pp..

FAUSTO, Boris (2001), O pensamento nacionalista autoritário. Rio de Janeiro: Ed. Jorge Zahar. 84 pp..

FRANCO, Afonso Arinos de Melo (1961), Estudos e discursos. São Paulo: Comercial. 408 pp..

GAUCHET, Marcel (2010), L'avènement de la démocratie (III): À l'épreuve des totalitarismes. Paris: Gallimard. 672 pp..

HOLLANDA, Cristina Buarque de and COSER, Ivo (2016), Realismos autoritário e liberal: aspectos da imaginação sobre representação política em fins do Século XIX e princípios do XX. DADOS. Vol. 59, № 03, pp. 903-946.

JANET, Paul (1887), Histoire de la science politique dans seus rapports avec la morale. Paris: Troisième édition. F. Alcan. 720 pp..

LAMOUNIER, Bolívar (2016), Liberais e antiliberais: a luta ideológica do nosso tempo. São Paulo: Cia. das Letras. 152 pp..

LAMOUNIER, Bolívar (2014), Tribunos, profetas e sacerdotes: intelectuais e ideologia no século XX. São Paulo: Cia. das Letras. 264 pp..

LAMOUNIER, Bolívar (2006), Formação de um pensamento político autoritário na Primeira República: uma interpretação. In: História geral da civilização brasileira. Tomo III: O Brasil republicano: estrutura de poder e economia (1889-1930). Edited by FAUSTO, Boris. Rio de Janeiro: Bertrand Brasil. pp. 371-388.

LAMOUNIER, Bolívar (1999), Ruy Barbosa e a construção institucional da democracia brasileira. Rio de Janeiro: Nova Fronteira; Fundação Casa de Ruy Barbosa. 152 pp..

LAMOUNIER, Bolívar (Ed) (1991), A opção parlamentarista. São Paulo: Idesp. 192 pp..

LAMOUNIER, Bolívar (Ed) (1982), A ciência política no Brasil: roteiro para um balanço crítico. In: A ciência política nos anos 80. Brasília: Editora da UnB. pp. 407-433.

LAMOUNIER, Bolívar (1981), A representação política: a importância de certos formalismos. In: Direito, cidadania e participação. Edited by LAMOUNIER, Bolívar; WEFFORT, Francisco and BENEVIDES, Maria Vitória. São Paulo: T.A. Queiroz Editor. pp. 233-260.

LAMOUNIER, Bolívar (1974a), Ideologia em regimes autoritários: uma crítica a Juan J. Linz. Estudos CEBRAP. № 07, pp. 67-92.

LAMOUNIER, Bolivar (1974b), Ideology and authoritarian regimes: theoretical perspectives and a study of the Brazilian case. Doctoral thesis. Los Angeles, University of California. 
LAMOUNIER, Bolívar (1968), Ideologia conservadora e mudanças estruturais. DADOS. Vol. 05, pp. 05-21.

LYNCH, Christian Edward Cyril (2017a), Entre a 'velha' e a 'nova' ciência política: continuidade e renovação acadêmica na primeira década da Revista DADOS (19661976). Dados. Vol. 60, №03, pp. 663-702.

LYNCH, Christian Edward Cyril (2017b), Conservadorismo caleidoscópico: Edmund Burke e o pensamento político do Brasil oitocentista. Lua Nova. Vol. 100, pp.313362.

LYNCH, Christian Edward Cyril (2016), Cartografia do pensamento político brasileiro: conceito, história, abordagens. Revista Brasileira de Ciência Política. № 19, pp. 75119.

LYNCH, Christian Edward Cyril (2015), Teoria pós-colonial e pensamento brasileiro na obra de Guerreiro Ramos: o pensamento sociológico (1953-1955). Cadernos do CRH. Vol. 28, № 73, pp. 27-45.

LYNCH, Christian Edward Cyril (2013), The institutionalization of Brazilian political thought in the social sciences. Wanderley Guilherme dos Santos' research revisited (1963-1978). Brazilian Political Science Review. Vol. 07, № 03, pp. 36-60.

MANNHEIM, Karl (1972), Liberdade, poder e planificação democrática. São Paulo: Mestre Jou. 416 pp..

McGERR, Michael (2003), A fierce discontent: the rise and fall of the progressive movement in America, 1870-1920. New York: Oxford University Press. 395 pp..

MERQUIOR, José Guilherme (1991), O liberalismo: antigo e moderno. Rio de Janeiro: Nova Fronteira. 260 pp..

MORGENTHAU, Hans J. (2003), A política entre as nações: a luta pelo poder e pela paz. Brasília: Editora Universidade de Brasília. 1.152 pp..

NABUCO, Joaquim (1997), Um estadista do Império. Rio de Janeiro: Topbooks. 1052 pp..

POCOCK, John G. A. (2003), Barbarism and religion. Vol. 01. New York: Cambridge University Press. 356 pp..

RAMOS, Alberto Guerreiro (1995), Introdução crítica à sociologia brasileira. Rio de Janeiro: Editora da UFRJ. 235 pp..

RAMOS, Alberto Guerreiro (1983), A inteligência brasileira na década de 1930, à luz da perspectiva de 1980. In: A Revolução de 1930: seminário internacional realizado pelo Centro de Pesquisa e Documentação de História Contemporânea do Brasil (CPDOC) da Fundação Getúlio Vargas. Brasília: Editora Universidade de Brasília. pp. 527-548. 
RAMOS, Alberto Guerreiro (1966), Administração e estratégia do desenvolvimento: elementos de uma sociologia especial da administração. Rio de Janeiro: FGV. 453 pp..

SANTOS, Wanderley Guilherme (1978), Ordem burguesa e liberalismo político. Rio de Janeiro: Duas Cidades. 172 pp..

STERNHELL, Zeev (2006), Les anti-Lumières: une tradition du XVIIe siècle à la guerre froide. Paris: Fayard. 594 pp..

STERNHELL, Zeev (1994) The birth of fascist ideology. Princeton: Princeton University Press. 352 pp.

STERNHELL, Zeev (1978), La droite révolutionnaire, 1885-1914: Les origines françaises du fascisme Paris: Seuil. 441 pp..

TORRES, Alberto (1981), A organização nacional. Brasília: UnB. 331 pp..

TORRES, Alberto (1914), A organização nacional. Rio de Janeiro: Tipografia Nacional. $351 \mathrm{pp}$.

VENTURI, Franco and FLORENZANO, Modesto (2003), Utopia e reforma no Iluminismo. Bauru: EDUSC. 274 pp..

VIANNA, Francisco José de Oliveira (1999), Instituições políticas brasileiras. Volume II. Brasília: Senado Federal. 591 pp..

VIANNA, Francisco José de Oliveira (1974), Instituições políticas brasileiras. Volume II. Rio de Janeiro: Record. 248 pp..

VIANNA, Francisco José de Oliveira (1930), Problemas de política objetiva. São Paulo: Companhia Editora Nacional. 245 pp..

VIANNA, Francisco José de Oliveira (1922), O idealismo na evolução política do Império e da República. São Paulo: Biblioteca d'O Estado de São Paulo. 96 pp.. 